УДК 378.011.3-051:78

DOI https://doi.org/10.26661/2522-4360-2021-2-36

\title{
МЕТОДИЧНЕ ЗАБЕЗПЕЧЕННЯ ФОРМУВАННЯ ІНТЕРПРЕТАТОРСЬКОӤ КУЛЬТУРИ У МАЙБУТНІХ ВЧИТЕЛІВ МУЗИКИ
}

\author{
Лу Сін \\ аспірантка кафедри теорії та методики постановки голосу \\ Національний педагогічний університет імені М. П. Драгоманова \\ вул. Пирогова, 9, Київ, Украӥна \\ orcid.org/0000-0002-7028-0488 \\ lu.sin.vocal@gmail.com
}

\begin{abstract}
Ключові слова: інвениія, імітація, ескізне вивчення твору, музичне мислення, виконавська програмність, візуальний компонент, слухові уявлення.
\end{abstract}

У роботі доведено, що музичне виконавство має два полюси: інтенцію (створення нового) та імітацію (копіювання), а інтерпретація (розуміння авторського твору) їх поєднує, хоча і не в рівній пропорції, при цьому зростає значущість або виконавської компоненти, або авторського задуму. Відображено процес створення комплексу методичного забезпечення формування інтерпретаторської культури у майбутніх вчителів музики. Цей комплекс включає такі методики: «Вивчення структури змісту інтерпретаційної культури», «Ескізне вивчення твору», «Розвиток музичного мислення у студентів». Методика «Вивчення структури змісту інтерпретаційної культури» включає такі елементи структури та їх пояснення, як: музичний звук або тон; зміна тональності; фактура; інтонація; художній образ; музичний темп; музична драматургія; тема; авторська присутність; виконавська програмність; візуальний компонент; концертна програма (тематична чи калейдоскопічна).

Методика «Ескізне вивчення твору», не передбачає публічного виступу, проте дає змогу знайомитися 3 різними композиторами та складними творами, оскіьки процес навчання закінчується без доведення високого ступеня завершеності оволодіння музичним матеріалом. Обов'язки педагога помітно змінюються під час ескізного вивчення творів. Насамперед зменшується кількість занять, на яких студент здає ескізно вивчені твори. Оцінюються вони теж за іншими критеріями.

Методика «Розвиток музичного мислення у студентів» пропонує студентам, щоб гарно виконати твір, добре уявити собі в усіх деталях його майбутнє звучання, тобто мати перед внутрішнім зором щось як ідеальний зразок. Наведено спеціальні прийоми названої методики, що полегшують внутрішньослухову роботу. Виявлено закономірність: чим зрозуміліший та чіткіший слуховий прообраз, тим якіснішим буде виконання твору. Слухові уявлення ведуть до якісного покращення безпосередньо інтерпретаційних результатів і до подальшого удосконалення художньої складової частини виконавства.

Наступним етапом дослідження буде експериментальна робота 3 практичної реалізації комплексу методик формування інтерпретаційної культури у майбутніх учителів музики. 


\title{
METHODOLOGICAL PROVIDENCE OF FORMATION OF INTERPRETATION CULTURE OF FUTURE MUSIC TEACHERS
}

\author{
Lu Xing \\ Postgraduate Student at the Department of Theory and Methods of Voice Production \\ National Pedagogical Dragomanov University \\ Pyrogova str., 9, Kyiv, Ukraine \\ orcid.org/0000-0002-7028-0488 \\ lu.sin.vocal@gmail.com
}

Key words: invention, imitation, sketch study of a work, musical thinking, performance programmability, visual component, auditory representations.
The paper proves that musical performance has two aspects: intention (creation of a new one) and imitation (copying), and interpretation (understanding of the author's work) combines them, although not in equal proportions, while the importance of either the performance component or the author's idea increases. The process of creating a set of methodological providence for the formation of interpretive culture of future music teachers is reflected. This complex includes the following methods: "Study of the structure of the content of interpretive culture", "Sketch study of the work", "Development of musical thinking in students". The method of "Study of the structure of the content of interpretive culture" includes the following elements of the structure and their explanation: musical sound or tone; change of tonality; musical texture; intonation; artistic image; musical tempo; musical drama; topic; author's presence; performance programmability; visual component; concert program (thematic or kaleidoscopic).

The method of "Sketch study of the work", which does not involve public performance, but allows one to get acquainted with various composers and complex works, as the learning process ends without proving a high degree of completion of mastering the musical material. The responsibilities of the teacher change significantly during the sketch study of the works. First of all, the number of classes in which the student submits sketched works decreases. They are also evaluated by other criteria.

The method of "Development of musical thinking in students" offers students to perform well, before that one need to have a good idea, in all its details, its future sound, that is, to have before the inner vision of something as a perfect example. There are special techniques of this method that facilitate intraauditory work. A regularity has been revealed - the clearer auditory prototype leads to the better the performance of the work. Auditory representations lead to a qualitative improvement of directly interpretive results and to further improvement of the artistic component of performance.

The next stage of the research will be experimental work on the practical implementation of set of methods for the formation of interpretive culture of future music teachers.
Постановка проблеми. Поняття інтерпретації у мистецтві до порівняно недавнього часу використовувалося головним чином у музичному виконавстві для позначення суттєвої сторони діяльності музиканта (співака, диригента, інструменталіста) тлумачення, відповідно до власних установок та потреб (що враховують також контекстні фактори типові риси епох створення та виконання музичного твору), його художнього змісту та стилістики.

Так, М. Берлянчик у своїй роботі розділяє первинну творчість автора-композитора, який ство- рює музику, та вторинну творчість виконавцяінтерпретатора, який створює твір виконавського мистецтва $[1$, с. 111$]$. Проте можна згадати публікацію М. Корноухова, який інтерпретаційну культуру учня-музиканта трактує як найважливішу професійно-особистісну якість, як необхідний елемент успішної соціалізації майбутнього фахівця [7].

Інтерпретація музичного тексту - це ядро, центр творчої діяльності виконавця. Це той суб'єктивний план спілкування з композитором, який поряд iз науково-практичним, методичним підходом до 
твору передбачає співпричетність, залучення до духовного світу творця, що дає змогу стати співрозмовником минулої культури та увійти в іії атмосферу «співавтором» музичного твору [2].

На думку О. Ляшенко, інтерпретація творів мистецтва $€$ цілісним утворенням, яке характеризує єдність і взаємозв'язок кількох складників, таких як текстуальна (індивідуально авторська), змістова (історична) та психологічна інтерпретація. Інтерпретація музичного твору обов'язково містить ретроспективне вивчення творів мистецтва (аналіз об'єктивних даних про твір, смисл та значення, які втілені в ньому) та особливу духовну діяльність свідомості, де суттєву роль відіграє досвід інтерпретатора у спілкуванні з мистецтвом [8].

Визначення інтерпретаційної культури майбутнього вчителя музики дає М. Демір: «це цілісне інтегративне утворення, яке виражається в розумінні та тлумаченні педагогічної дійсності у всій сукупності іiі процесів, подій, структур, міжособистісних відносин, що засноване на комплексі знань, умінь і навичок, а також на творчому досвіді, спрямованому на виявлення сенсу музично-педагогічних текстів» [4]. Сформованість інтерпретаційної культури вчителя музики впливає на ефективність педагогічного процесу та донесення до учнів ціннісних смислів мистецтва [5]. Тому проблема інтерпретаційної культури сьогодні продовжує мати актуальний характер.

Для дослідження формування інтерпретаційної культури у майбутніх вчителів музики автор статті провів детальний аналіз філософських та психолого-педагогічних основ цього феномену. Проте залишилася невирішеною проблема методичного забезпечення названого процесу.

Мета статті. Головною ідеєю статті є відображення створення комплексу методичного забезпечення формування інтерпретаторської культури у майбутніх учителів музики. цей комплекс включає методики, які $є$ удосконаленням існуючих, зокрема такі: «Вивчення структури змісту інтерпретаційної культури», «Ескізне вивчення твору», «Розвиток музичного мислення у студентів».

Виклад основного матеріалу дослідження.

На думку Е. Гуренко, умовами художньої інтерпретації є: 1) об'єкт, 2) посередник-інтерпретатор і 3) продукт виконавської діяльності. Цим трьом умовам відповідають три фази процесу художньої інтерпретації: 1) сприйняття об'єкта, 2) його осмислення інтерпретатором (розуміння) та 3) створення витвір мистецтва «другого порядку» (тлумачення) [3].

На початковому етапі практичної роботи із формування інтерпретаційної культури у майбутніх вчителів музики студенти мали засвоїти, що активність інтерпретатора спрямована не на самовираження (таке право має лише автор), а на власне індивідуальне розуміння авторського задуму твору, де під дією нової творчої особистості зміст композиторського опусу безповоротно підлягає зміні. Крім того, вони повинні були зрозуміти, що музичне виконавство має два полюси: інвенцію та імітацію (рис. 1), а інтерпретація їх поєднує, хоча і не в рівній пропорції, при цьому зростає значущість або виконавської компоненти, або авторського задуму.
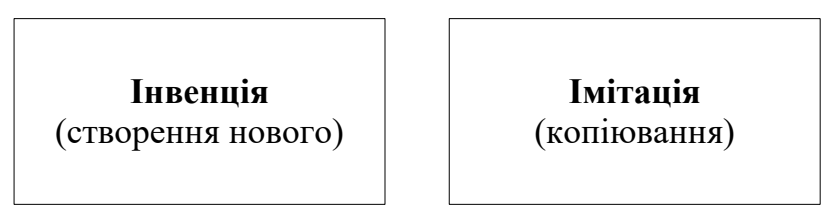

\section{Рис. 1. Полюси інтерпретації (складено автором)}

Отже, під інтерпретацією студенти мають розуміти процес особистісного діалогу виконавця, що здійснюється звучанням, який розрахований на слухача та поєднує відтворення й оновлення композиторського твору.

Особливою формою інтерпретації вважається виконавська редакція. Це канонізована, «задокументована інтерпретація», що належить видатному виконавцю. В нотному тексті композиторський опус отримує виконавські уточнення, які коригують звучання та стосуються динаміки, фразування, штрихів, аплікатури, дихання, темпу й агогіки, розшифрування мелізмі тощо [3]. Виконавська редакція описується однією особою, а актуалізуватися може іншими виконавцями.

Розпочнемо з методики «Вивчення структури змісту інтерпретаційної культури». Вона включала елементи структури та їх пояснення.

1. Музичний звук або тон. Саме для виконавця важливим $€$ знаходження адекватної звукової форми композиторського задуму. Наявність власного звукового «іміджу» часто ускладнює завдання, що стоїть перед виконавцем. Адже йому необхідно знайти оптимальний для кожного твору «характер» звуку: багатий чи глибокий, оксамитовий чи легкий тощо. Намагаючись отримати максимально адекватне звучання, студент має коригувати забарвлення свого голосу.

2. Зміна тональності. Вона потрібна для отримання виконавської виразності. Так, багато романсів і пісень різних композиторів можна спокійно переносити в тональність, яка $є$ зручною для виконання.

3. Фактура. Її відчуття потрібне для професійної чутливості виконавця. Від того, як чує голоси виконавець, залежить дуже багато.

4. Інтонація. Вона дозволяе виконавцю ставити свій власний акцент (образно-смисловий) 
у творі, при цьому використовувати жанрові особливості твору, його стильові джерела, задіяти естетичні вподобання та власну драматургію. Отже, у виконавця є багатий вибір смислових відтінків інтонації.

5. Художній образ. Виконавець має передати його конкретно, при цьому поєднати в ньому голосову і просторову координати, створити хронотоп твору.

6. Музичний темп. Він має бути оптимальним, оскільки від нього залежать і його короткотермінові зміни.

7. Музична драматургія. Виконавець повинен вибудовувати і поєднати музичні образи в одну цілісність, при цьому дотримуючись балансу внутрішньої статики та динаміки.

8. Tема. Вона визначає те, чому присвячено твір, а ідея визначає, як саме буде вирішуватися тема, які вона має смислові акценти. Студенти самостійно вибирали твір та його аналізували.

9. Авторська присутність. Йдеться про відображення в музиці особистості композитора, що естетично організовує художню цілісність. До атрибутів авторської присутності відносять: думки і почуття автора, його думку, індивідуальну картину світу, пріоритети тощо. Розібратись у цьому студентам допомагала структура особистості, яка розроблена психологами та поєднує в собі такі аспекти та характеристики:

- біологічні - темперамент, вік, стать;

-психологічні - емоції, почуття, сприйняття, волю, спосіб мислення тощо;

- світогляд - бажання, інтереси, ідеали, переконання, прагнення.

10. Виконавська програмність. У виконавській програмі творів, яка має індивідуально-суб'єктивний характер, має бути ще й такий елемент, як візуальні уявлення.

11. Візуальний компонент. Цей компонент інтерпретації змісту музичного твору здатний підсилювати або послаблювати художнє враження від його виконання. Адже він включає зовнішній вигляд виконавця, його поведінку на сцені, відносини $з$ музичним інструментом та іншими виконавцями.

12. Концертна програма. Вона може бути тематичною чи калейдоскопічною. Перша присвячується, як правило, одному композитору (авторський, ювілейний, меморіальний концерти), що дозволяє розкрити стиль композитора, його «творчий портрет». Проте тематичний характер може мати i програма концерту, що присвячена одній епосі або одній художній темі. Ще більші можливості криються в циклах концертів, але тут потрібно враховувати послідовність виконання творів. У гарно складеній програмі твори утворюють цикл більш високого порядку, який має нові художні смисли. При цьому виникають нові інтертекстуальні зв'язки, твориться новий контекст, що значно розширює смислове поле музики.

Калейдоскопічна, або сюїтна програма, в якій концертні номери виступають кожний сам по собі. Така програма дає змогу виявити як композиторські, так і виконавські пласти музичного змісту.

Для розвитку навички інтерпретації, на нашу думку, підходить методика «Ескізне вивчення твору», яка не передбачає публічного виступу, проте дозволяє знайомитися 3 різними композиторами та складними творами, оскільки процес навчання закінчується без доведення до високого ступеня завершеності оволодіння музичним матеріалом. Останнім етапом цієї роботи стає етап, на якому студент охоплює в загальному і цілому образно-поетичний задум твору, отримує художньо достовірне, не викривлене уявлення про нього і як виконавець виявляється у стані донести до слухача цей задум.

До переваг цієї методики можна віднести:

1. Скорочуються строки розучування твору.

2. Збільшується кількість творів, що вивчаються.

3. Розширюється музичний кругозір за рахунок різноманітності творів.

4. Постійне збагачення новими знаннями, вміннями та навичками.

Ми поділяємо думку доктора педагогічних наук Г. Ципіна [9], що заняття, які будуються за принципами створення виконавських ескізів, можна віднести до найбільш результативних засобів не тільки загально-музичного розвитку, а й способів формування інтерпретаційної культури.

Отже, ми вважаємо, що ескізна форма роботи має право бути широко представлена у навчальному процесі. Тому висвітлимо основи нашої методики «Ескізне засвоєння вокального матеріалу».

1. Penepmyap. У розробленій нами методиці він має бути максимально різноманітним, стилістично багатим і багатоплановим, оскільки є основною базою цієї методики. У репертуарі має бути представлено значно ширше коло композиторських імен та творів, ніж те, яке використовується педагогом для заліково-екзаменаційних програм. Тут важливо, щоб твори подобалися студенту, викликали у нього інтерес та живий емоційний відклик. Тому бажано йти назустріч побажанням студента під час складання програмного переліку п’єс для ознайомлення. Насамкінець, репертуарна політика має бути більш сміливою і гнучкою.

2. Обов'язки педагога. Вони помітно змінюються під час ескізного вивчення творів. Насамперед зменшується кількість занять, на яких студент здає ескізно вивчені твори. Оцінюються вони теж за іншими критеріями. У подальших положеннях методики завдання педагога будуть конкретизовані. 
3. Основні проблеми методики. Особливо ті, що пов'язані $з$ інтерпретаційною культурою, повинні вирішуватися самими студентами. Завдання педагога при цьому - намітити кінцеву художню мету роботи, дати їй загальний напрям, підказати раціональні прийоми і способи вираження музики.

4. Прийоми $і$ способи виконання творів. У цій методиці вони теж мають свої особливості та певну трансформацію. Акцент на заняттях зміщується на цілісне втілення звукового образу, на загальне виконавське охоплення музичної форми, на спробу виконати твір емоційно, без остраху зробити помилку, допустити технічну помарку.

Ще однією методикою формування інтерпретаційної культури майбутніх учителів музики стала методика «Розвиток музичного мислення у студентів». Ми вважаємо, що для того, щоб гарно виконати твір, спочатку необхідно добре уявити собі в усіх деталях його майбутнє звучання, тобто мати перед внутрішнім зором щось у якості ідеального зразка. Наведемо спеціальні прийоми названої методики, що полегшують внутрішньослухову роботу студента.

1. Виконання п'єс навчальної програми в повільному темпі з наміром на «розвідку слухом», тобто уявляти наступне розгортання музики.

2. Виконання музичного твору способом пунктиру - одну фразу реальним голосом, а наступну про себе (подумки), при цьому потрібно зберігати відчуття неперервності, злитності руху звукового потоку.

3. Прослуховування творів у чужому виконанні - за одночасного прочитування відповідних нотних текстів.

4. Засвоєння музичного матеріалу, проникнення у нього, його виразну суть виключно через відтворення нотного тексту в думках за принципом: «бачу - чую».

До розумових дій відноситься виконавський внутрішньослуховий образ, оскільки він є новоутворенням, а не простою копією деякого звукового явища (твору). лише за таких умов цей образ може стати яскравим, повнокровним, емоційно багатим і змістовним. Діалектика цього механізму така: вона $\epsilon$ необхідною передумовою справжнього творчого музично-виконавського процесу, одним із обов'язкових його компонентів. Слухові уявлення можуть розвиватися, збагачуватись, перетворюватися та підніматися на більш високий рівень.

\section{Висновки.}

Мистецтво інтерпретації набуло інтенсивного розвитку, тоді як композиторська творчість і виконавство стали набувати все більшої самостійності, а виконавець - можливості інтерпретувати твори інших авторів. Музичне виконавство має два полюси: інтенцію та імітацію, а інтерпретація їх поєднує, хоча і не в рівній пропорції, при цьому зростає значущість або виконавської компоненти, або авторського задуму.

Інтерпретаційна культура майбутнього вчителя музики - це цілісне інтегративне утворення, яке виражається в розумінні та тлумаченні педагогічної дійсності у всій сукупності ії процесів, подій, структур, міжособистісних відносин, що засноване на комплексі знань, умінь і навичок, а також на творчому досвіді, спрямованому на виявлення сенсу музично-педагогічних текстів. У результаті виконавської редакції виконавський пласт ускладнюється: вихідний композиторський пласт збагачується редакцією і на стадії виконавства перетворюється в «двічі інтерпретацію».

Описана методика «Вивчення структури змісту інтерпретаційної культури» включала такі елементи структури та їх пояснення, як: музичний звук або тон; зміна тональності; фактура; інтонація; художній образ; музичний темп; музична драматургія; тема; авторська присутність; виконавська програмність; візуальний компонент; концертна програма.

Потенційні ресурси ескізної роботи над творами значні і багатопланові для інтерпретаційної діяльності, проте отримати ефект студенти зможуть тільки у разі регулярної і систематичної роботи над творами.

У свідомості студента мають бути запрограмовані всі без винятку складові частини, з яких складається реальний звуковий процес: що має бути виконано і як само. Існує закономірність: чим зрозуміліший та чіткіший слуховий прообраз, тим якіснішим буде виконання твору. Слухові уявлення ведуть до якісного покращення безпосередньо інтерпретаційних результатів і до подальшого удосконалення художньої складової частини виконавства.

Наступним етапом дослідження буде експериментальна робота із практичної реалізації комплексу методик формування інтерпретаційної культури у майбутніх учителів музики.

\section{ЛІТЕРАТУРА}

1. Берлянчик М. Способность художественной интерпретации - необходимый критерий приобщенности к искусству и фактор духовно-эстетического развития личности // Искусство и личность. В 2 кн. Кн.1. Проблемы художественного образования и музыкального исполнительства / М. Берлянчик. М., 2009. С. 110-112.

2. Гаркуша Л.І. Виконавська інтерпретація музичних творів у структурі професійної підготовки майбутнього педагога-музиканта / Л.І. Гаркуша, О.С. Економова // Професійна мистецька освіта 
і художня культура: виклики XXI століття : матер. II Міжнарод. наук.-практ. конф., 14-15 квіт. 2016 p. C. $520-529$.

3. Гуренко Е.Г. Проблемы художественной интерпретации (философский анализ) / Е. Г. Гуренко. Новосибирск: Наука, 1982. - 256 с.

4. Демір М.І. Впровадження герменевтичного підходу в навчально-виховний процес як педагогічна умова формування інтерпретаційної культури майбутнього вчителя музики / М.I. Демір // Народна освіта. Електронне наукове фахове видання. Вип. № 3 (27). - 2015. [Електронний ресурс] - Режим доступу: https://www.narodnaosvita.kiev.ua/?page_id=3710

5. Завалко К.В. Теоретико-методичні аспекти формування інтерпретаційної культури майбутнього вчителя музики / К.В. Завалко // Теоретичні питання культури, освіти та виховання: збірник наукових праць. Випуск 35 / За заг. ред. академіка АПН України Євтуха М.Б. - К.: Вид. центр КНЛУ, 2008. - C. 88-90.

6. Казанцева Л.П. Содержание музыкального произведения в контексте музыкальной жизни: Учебное пособие. - 3-е издание, стереот. СПб: Изд-во «Лань», 2019. 192 с.

7. Корноухов М.Д. Формирование интерпретационной культуры будущего учителя музыки как компонент методологии педагогики музыкального образования // Музыкальное искусство и образование. 2015. № 2 (10). URL: https://cyberleninka.ru/article/n/formirovanie-interpretatsionnoy-kulturybuduschego-uchitelya-muzyki-kak-komponent-metodologii-pedagogiki-muzykalnogo-obrazovaniya (дата обращения: 21.09.2020).

8. Ляшенко О. Художньо-педагогічна інтерпретація музичного твору в професійній підготовці майбутніх учителів музики: автореф. дис... канд. пед. наук; 13.00.04 / О. Ляшенко. - Київ : НПУ імені МП. Драгоманова, 2001. - 22 с.

9. Цыпин Г.М. Музыкальное исполнительство. Исполнитель и техника: учебник / Г.М. Цыпин. 2-е изд., исправ. и доп. Москва: Изд-во Юрайт, 2020. 193 с.

\section{REFERENCES}

1. Berljanchik, M. (2009). Sposobnost' hudozhestvennoj interpretacii - neobhodimyj kriterij priobshhennosti k iskusstvu i faktor duhovno-jesteticheskogo razvitija lichnosti [The ability of artistic interpretation is a necessary criterion for involvement in art and a factor in the spiritual and aesthetic development of a person]. Iskusstvo $i$ lichnost'. Book 1. Problemy hudozhestvennogo obrazovanija i muzykal'nogo ispolnitel'stva. M. P. 110-112.

2. Gharkusha, L.I. (2016). Vykonavsjka interpretacija muzychnykh tvoriv u strukturi profesijnoji pidghotovky majbutnjogho pedaghogha-muzykanta [Performing interpretation of musical works in the structure of professional training of a future music teacher]. Profesijna mystecjka osvita i khudozhnja kuljtura: vyklyky XX stolittja : mater. II Mizhnarod. nauk.-prakt. konf., 14-15 kvit. P. 520-529.

3. Gurenko, E.G. (1982). Problemy hudozhestvennoj interpretacii (filosofskij analiz) [Problems of artistic interpretation (philosophical analysis)]. Novosibirsk: Nauka. 256 p.

4. Demir, M.I. (2015). Vprovadzhennja ghermenevtychnogho pidkhodu v navchaljno-vykhovnyj proces jak pedaghoghichna umova formuvannja interpretacijnoji kuljtury majbutnjogho vchytelja muzyky [Introduction of the hermeneutic approach in the educational process as a pedagogical condition for the formation of the interpretive culture of the future music teacher]. Narodna osvita. Elektronne naukove fakhove vydannja. \#3 (27). Retrieved from: https://www.narodnaosvita.kiev.ua/?page_id=3710.

5. Zavalko, K.V. (2008). Teoretyko-metodychni aspekty formuvannja interpretacijnoji kuljtury majbutnjogho vchytelja muzyky [Theoretical and methodological aspects of the formation of the interpretive culture of the future music teacher]. Teoretychni pytannja kuljtury, osvity ta vykhovannja: zbirnyk naukovykh pracj. V 35. K.: Vyd. centr KNLU. P. 88-90.

6. Kazanceva, L.P. (2019). Soderzhanie muzykal'nogo proizvedenija v kontekste muzykal'noj zhizni: Uchebnoe posobie [The Content of a Musical Work in the Context of Musical Life: Tutorial]. 3-d ed. SPb: Izd-vo «Lan'», $192 \mathrm{p}$.

7. Kornouhov, M.D. (2015). Formirovanie interpretacionnoj kul'tury budushhego uchitelja muzyki kak komponent metodologii pedagogiki muzykal'nogo obrazovanija [Formation of the interpretive culture of the future music teacher as a component of the pedagogy methodology of music education]. Muzykal'noe iskusstvo i obrazovanie. \#2 (10). Retrieved from: https://cyberleninka.ru/article/n/formirovanieinterpretatsionnoy-kultury-buduschego-uchitelya-muzyki-kak-komponent-metodologii-pedagogikimuzykalnogo-obrazovaniya.

8. Ljashenko, O. (2001). Khudozhnjo-pedaghoghichna interpretacija muzychnogho tvoru v profesijnij pidghotovci majbutnikh uchyteliv muzyky: avtoref. dys... kand. ped. nauk; 13.00 .04 [Artistic and pedagogical interpretation of a musical work in the professional training of future music teachers: dissertation abstract, ped. science; 13.00.04]. Kyiv: NPU imeni MP. Draghomanova. 22 p.

9. Cypin, G.M. (2020). Muzykal'noe ispolnitel'stvo. Ispolnitel' i tehnika: uchebnik [Musical performance. Artist and technique: textbook]. 2-d ed. Moskva: Izd-vo Jurajt. 193 p. 